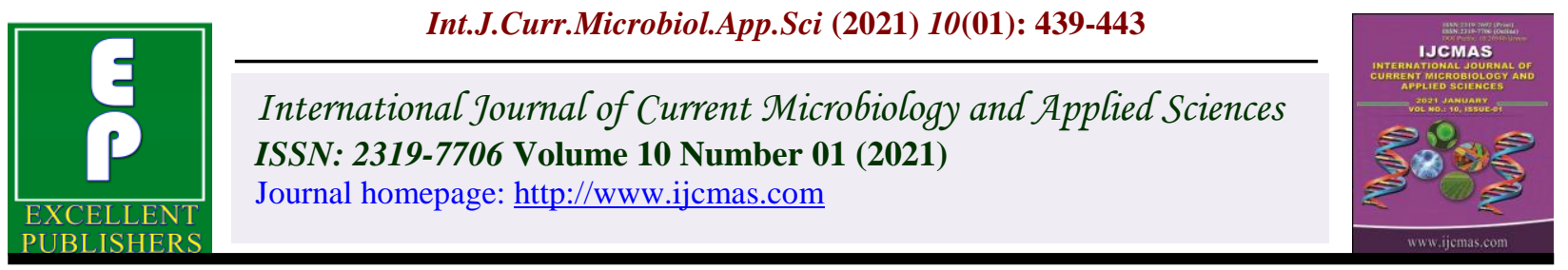

\title{
Survey for the Incidence of Fusarium Wilt of Chickpea in Major Chickpea Growing Districts of Northern Karnataka, India
}

\author{
K. L. Nandeesha* and Shalini N. Huilgol \\ Department of Plant pathology, College of Agriculture, Vijayapura, India \\ *Corresponding author
}

\section{A B S T R A C T}

\begin{tabular}{|l|}
\hline Ke y w or d s \\
$\begin{array}{l}\text { Chickpea wilt, } \\
\text { Fusarium } \\
\text { oxysporum f. sp. } \\
\text { ciceri }\end{array}$ \\
\hline Article Info \\
\hline $\begin{array}{l}\text { Accepted: } \\
\text { 04 December 2020 } \\
\text { Available Online: } \\
\text { 10 January 2021 }\end{array}$ \\
\hline
\end{tabular}

Chickpea (Cicer arietinum L.) is one of the most important pulse crop grown all over India. Chickpea wilt caused by Fusarium oxysporum f. sp. ciceri is one of the major disease on chickpea in Northern Karnataka, which is soil and seed borne. Heavy inoculum in the soil and favorable environment condition results in the death of infected plant and therefore total yield loss. A random roving survey was carried out in major chickpea growing districts of Northern Karnataka, viz., Vijayapura, Bagalkote, Gadag and Kalburgi in 2017-18 to know the disease prevalence and its severity in various locations. Survey results revealed that Bagalkote district had high disease incidence with 27.19 per cent followed by Kalburgi district with 24.90 per cent.

\section{Introduction}

Chickpea is (Cicer arietinum L.) is one of the most important and oldest pulse crop after beans and peas. Chickpea seeds contain an average of 23 per cent protein, 38-59 per cent carbohydrate, $4.8-5.5$ per cent oil, 47 per cent starch, 5 per cent fat, 6 per cent crude fibre, 6 per cent soluble sugar and 3 per cent ash, minerals such as calcium (202 mg), phosphorous (312 mg), iron (10.2 mg), vitamin C (3.0 mg), calorific value $(360 \mathrm{cal})$, small amounts of B complex, fibre (3.9 g) and moisture $(9.8 \mathrm{~g})$. There are two main commercial types of chickpea. The Desi type with smaller and darker coloured seeds which may vary from yellow to black and the Kabuli type with large, smooth and light coloured seeds (Singh, 1985).

Chickpea crop is attacked by 172 pathogens (67 fungi, 22 viruses, 3 bacteria, 80 nematodes and phytoplasma) across the world (Nene et al., 1996). Among all, only a few of them have the potential to devastate the crops. Some of the serious diseases in order of their importance are wilt, dry root rot, collar rot, colletotrichum blight, alternaria blight, rust and ascochyta blight caused by Fusarium oxysporum f. sp. ciceri, Macrophomina phaseolina, Sclerotium rolfsii, Colletotrichum dematium, Alternaria alternata, Uromyces 
ciceris-arietini and Ascochyta rabiei respectively (Nene et al., 1984).

Losses of chickpea from Fusarium wilt have been reported to vary from 10 to 15 per cent (Jalali and Chand., 1991; Trapero-Casas and Jimenez-Diaz., 1985) but losses of up to 70 per cent have been reported in some years in Northern India and Pakistan (Grewal and Pal., 1970). As a facultative saprophyte, Fusarium oxysporum f. sp. ciceri can survive in soil and on crop residues as chlamydospores for upto six years. The pathogen is also seed-borne and may therefore be spread by means of infected seed (Haware et al., 1978). Fusarium oxysporum f. sp. ciceri is considered to be a major threat to chickpea production in India, Iran, Pakistan, Nepal, Burma, Spain and Tunisia (Jalali and Chand., 1991). In the current study, a random roving survey was carried out in major chickpea growing districts of Northern Karnataka, viz., Vijayapura, Bagalkote, Gadag and Kalburgi in 2017-18 to know the disease prevalence and its severity in various locations.

\section{Materials and Methods}

Random roving method of survey was carried out to record the severity of Fusarium wilt in chickpea. The survey was conducted during rabi 2017-18, in major chickpea growing districts of Northern Karnataka viz., Vijayapura, Bagalkote, Kalburgi and Gadag, observations on disease incidence, severity as well as age of crop was noted down. Disease incidence was assessed by counting the number of plants showing wilting symptoms in three representative 75-100 plants randomly chosen in each field as mentioned by Smitha et al., (2015). The disease incidence in the fields was assessed with the following formula.

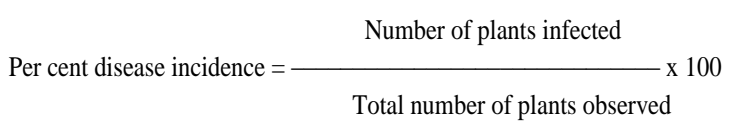

\section{Results and Discussion}

A random roving survey for disease incidence was conducted in major chickpea growing areas of Northern Karnataka, viz, Vijayapura, Bagalkote, Kalburgi and Gadag, during Rabi 2017-18 to collect the diseased samples for further investigation in laboratory.

The disease incidence was assessed by counting the number of plants showing symptoms in 75-100 plants randomly chosen in the field assessed. The per cent incidence of Fusarium wilt was recorded.

The highest per cent disease incidence was recorded at Vajjala village of Bagalakote district $(51.25 \%)$ and lowest was at Managooli village of Vijayapura district (9.11 $\%$ ) (Table 1).

In Vijayapura district, the disease incidence ranged from 9.11 per cent (Mangooli) to 24.55 per cent (Basavana Bagevadi). In Bagalakote district, the disease incidence ranged from 13.50 per cent (Anagawadi) to 51.25 per cent (Vajjala). In Gadag district the disease incidence ranged from 17.61 per cent (Kurligeri) to 23.21per cent (Ron). In Kalburgi the disease incidence was ranged from 19.86 per cent (Jeratagi) to 29.33 per cent (Kotnur).

Among the districts covered under survey, maximum disease incidence was recorded in Bagalakote district $(27.19 \%)$ followed by Kalburgi district $(24.90 \%)$ whereas minimum disease incidence was recorded in Vijayapura district (16.48) (Table 2, Fig. 1).

The mean disease incidence of irrigated and rainfed areas at taluka level is depicted in Table 2. Under irrigated condition the least disease incidence was in Kalburgi taluka (27.49 per cent) of Kalburgi district and highest disease incidence was in Hunagunda 
(50.55) Taluka of Bagalakote district. In case of rainfed condition highest wilt incidence was in Jewargi Taluka of Kalburgi district (22.31 per cent) and lowest wilt incidence was seen in Vijayapura taluka of Vijayapura district (13.29 per cent). Hence as a whole it depicts that the disease incidence in different location varied with respect to its geographical condition, agroclimatic condition, stage of the crop etc. In rainfed condition the average disease incidence was 18.24 per cent and in irrigated condition it was 39.02 per cent. The disease incidence was severe in the later stages of the crop and the wilt incidence varied from 16.48 per cent to 27.19 per cent.

Table.1 Incidence of Fusarium wilt of chickpea in Northern districts of Karnataka during 2017-18

\begin{tabular}{|c|c|c|c|c|c|}
\hline District & Taluka & Village name & $\begin{array}{l}\text { Stage of the } \\
\text { crop }\end{array}$ & $\begin{array}{c}\text { Crop } \\
\text { grown } \\
\text { condition }\end{array}$ & $\begin{array}{l}\text { Per cent } \\
\text { disease } \\
\text { incidence }\end{array}$ \\
\hline \multirow[t]{6}{*}{ Vijayapura } & \multirow[t]{2}{*}{ Vijayapura } & Hittinahalli & Flowering & Rainfed & 17.47 \\
\hline & & Managooli & Podding & Rainfed & 9.11 \\
\hline & \multirow[t]{2}{*}{ Sindagi } & Chikkarugi & Vegetative & Rainfed & 16.36 \\
\hline & & Aheri & Podding & Rainfed & 19.20 \\
\hline & \multirow[t]{2}{*}{$\begin{array}{l}\text { Basavana } \\
\text { Bagevadi }\end{array}$} & $\begin{array}{l}\text { Basavana } \\
\text { Bagevadi }\end{array}$ & Podding & Rainfed & 24.55 \\
\hline & & Golasangi & Flowering & Rainfed & 12.21 \\
\hline \multirow[t]{6}{*}{ Bagalkote } & \multirow[t]{2}{*}{ Bagalkote } & Simikeri & Podding & Rainfed & 14.51 \\
\hline & & Shirur & $\begin{array}{l}\text { Pre } \\
\text { Flowering }\end{array}$ & Rainfed & 15.25 \\
\hline & \multirow[t]{2}{*}{ Hunagunda } & Hunagunda & Flowering & Irrigated & 49.85 \\
\hline & & Vajjala & $\begin{array}{l}\text { Pre } \\
\text { Flowering }\end{array}$ & Irrigated & 51.25 \\
\hline & \multirow[t]{2}{*}{ Bilgi } & Anagawadi & Vegetative & Rainfed & 13.50 \\
\hline & & Badangadi & $\begin{array}{l}\text { Pre } \\
\text { Flowering }\end{array}$ & Rainfed & 18.80 \\
\hline \multirow[t]{6}{*}{ Gadag } & \multirow[t]{2}{*}{ Nargund } & Kurligeri & Flowering & Rainfed & 17.61 \\
\hline & & Banahatti & Flowering & Rainfed & 22.35 \\
\hline & \multirow[t]{2}{*}{ Ron } & Ron & Podding & Rainfed & 23.21 \\
\hline & & Naregal & Podding & Rainfed & 19.75 \\
\hline & \multirow[t]{2}{*}{ Gadag } & Hulkoti & Podding & Rainfed & 19.63 \\
\hline & & Binkadakatti & Podding & Rainfed & 20.21 \\
\hline \multirow[t]{4}{*}{ Kalburgi } & \multirow[t]{2}{*}{ Jewargi } & Jeratagi & Podding & Rainfed & 19.86 \\
\hline & & Moratagi & Flowering & Rainfed & 24.77 \\
\hline & \multirow[t]{2}{*}{ Kalburgi } & Kalburgi & Podding & Irrigated & 25.65 \\
\hline & & Kotnur & Podding & Irrigated & 29.33 \\
\hline
\end{tabular}


Table.2 Mean per cent disease incidence of Fusarium wilt of chickpea in different district and taluka during 2017-18

\begin{tabular}{|c|c|c|c|c|c|c|}
\hline Sl.No. & District & Taluka & Rainfed & Irrigated & Taluka & District \\
\hline \multirow[t]{3}{*}{1} & \multirow[t]{3}{*}{ Vijayapura } & Vijayapura & 13.29 & - & 13.29 & \multirow[t]{3}{*}{16.48} \\
\hline & & Sindagi & 17.78 & - & 17.78 & \\
\hline & & Basavana Bagevadi & 18.38 & - & 18.38 & \\
\hline \multirow{3}{*}{2} & \multirow[t]{3}{*}{ Bagalkote } & Bagalkote & 14.88 & - & 14.88 & \multirow[t]{3}{*}{27.19} \\
\hline & & Hunagunda & - & 50.55 & 50.55 & \\
\hline & & Bilgi & 16.15 & - & 16.15 & \\
\hline \multirow{3}{*}{3} & \multirow[t]{3}{*}{ Gadag } & Nargund & 19.98 & - & 19.98 & \multirow[t]{3}{*}{20.46} \\
\hline & & Ron & 21.48 & - & 21.48 & \\
\hline & & Gadag & 19.92 & - & 19.92 & \\
\hline \multirow[t]{2}{*}{4} & \multirow[t]{2}{*}{ Kalburgi } & Jewargi & 22.31 & - & 22.31 & \multirow[t]{2}{*}{24.90} \\
\hline & & Kalburgi & & 27.49 & 27.49 & \\
\hline \multicolumn{3}{|c|}{ Mean disease incidence (\%) } & 18.24 & 39.02 & & \\
\hline
\end{tabular}

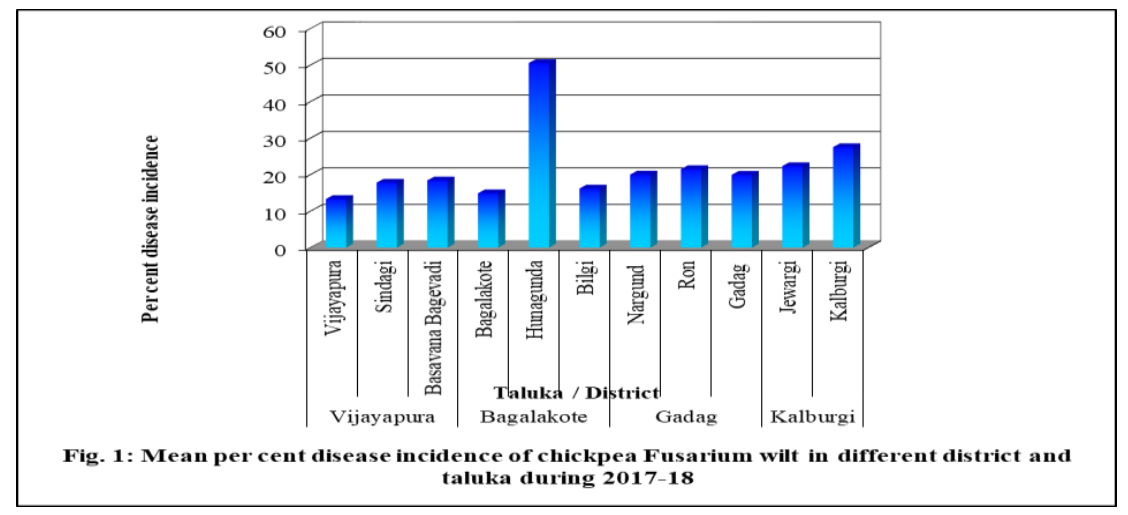

The data with respect to wilt incidence in different places depicted that, the disease incidence varied from place to place due to varied agroclimatic conditions, cropping pattern, crop stage and cultural practices followed. Among the districts covered in the survey, highest disease incidence was observed in Bagalakote district with 27.19 per cent, followed by Kalburgi district with 24.90 per cent and the lowest disease incidence was noticed in Vijayapura district with 16.48 per cent wilt incidence.

Further, from the study of disease incidence in the different districts it was found that, the disease incidence was highest during the reproductive stage of the crop. The wilt incidence was prevalent more in reproductive phase of the crop as the nutrients drain to the reproductive part of the plant and due to imbalance supply of nutrients in the stem and root region (Ravichandran, 2015).

\section{References}

Grewal, J. S. and Pal, M., 1970, Fungal diseases of gram and arhar. Proc. of $4^{\text {th }}$ Workshop of Pulse Crops, Ludhiana, 169-170.

Haware, M. P., Nene, Y. L. and Rajeswari, R., 1978, Eradication of Fusarium oxysporum f. sp. ciceri transmitted in chickpea seed. Phytopathol., 68: 13641367. 
Jalali, B. L. and Chand, H., 1991, Chickpea wilt. In: Mukhopadhya, A. N., Chaube, H. S., Singh. U. S. and Kumar, J. (Eds.) Diseases of International Importance, Vol. 1, Prentice Hall, New Jersey, USA, pp. 7-10.

Nene, Y. L., Sheila, V. K. and Sharma, S. B., 1984, A world list of chickpea (Cicer arietinum $\mathrm{L}$.) and pigeonpea (Cajanus cajan (L.) Millsp.) pathogens. ICRISAT Pulse Path. Prog. Rep., 32: 19.

Nene, Y. L., Sheila, V. K. and Sharma, S. B., 1996, A World List of Chickpea and Pigeonopea Pathogens, $5^{\text {th }}$ edn. ICRISAT, Patancheru, India, p. 27.

Ravichandran, S. and Hegde, Y. R., 2015, Evaluation of fungicides against
Fusarium oxysporum f. sp. ciceri causing chickpea wilt. Chem. Sci. Rev. Lett., 4(16): 1042-1046.

Singh, U., 1985, Nutritional quality of chickpea (Cicer arietinum L.): current status and future research needs. Qualitas Plantarum Pl. Foods Human Nutri., 35: 339-351.

Smitha, K. P., Rajeswari, E., Alice, D. and Raguchander, T., 2015, Assessment of vascular wilt and dry root rot of pigeonpea in Tamil Nadu. Int. J. Trop. Agric., 33(3): 2145-2151.

Trapero-Casas, A. and Jiménez-Díaz, R. M., 1985, Fungal wilt and root rot diseases of chickpea in southern Spain. Phytopathol., 75: 1146-51.

\section{How to cite this article:}

Nandeesha, K. L. and Shalini N. Huilgol. 2021. Survey for the Incidence of Fusarium Wilt of Chickpea in Major Chickpea Growing Districts of Northern Karnataka, India. Int.J.Curr.Microbiol.App.Sci. 10(01): 439-443. doi: https://doi.org/10.20546/ijcmas.2021.1001.054 